\title{
RAPDs in representatives of the genus Sorex, including chromosome races of Sorex araneus
}

\author{
Natalia A. Illarionova*, Sergey G. Potapov \& Victor N. Orlov
}

\begin{abstract}
We analysed genetic divergence between species of the genus Sorex (S. araneus, $S$. caecutiens, $S$. minutus and $S$. minutissimus) using the RAPD (random amplified polymorphic DNA) method. We also examined RAPDs in 26 individuals of six chromosome races of the common shrew (Moscow, Ilomantsi, St. Petersburg, Neroosa, Penza, and Sok) from the European part of Russia. Nine primers were used for the detection of 24 to 79 fragments. The number of clearly identified DNA fragments by all primers was 539. Loci specific for different chromosome races of $S$. araneus were revealed. On the basis of summary matrices of the RAPD spectrum for nine primers, trees showing the genetic divergence were constructed. This study demonstrated the value of RAPDs for the analysis of relationship between species and chromosome races in Sorex.
\end{abstract}

KEY WORDS: common shrew, Sorex araneus, chromosome races, RAPDs, RAPD-PCR.

NataliaA. Illarionova [ina-u@mail.ru], Sergey G. Potapov, and Victor N. Orlov, A.N. Severtsov Institute of Ecology and Evolution, Russian Academy of Sciences, Leninskii pr. 33, Moscow 119071, Russia.

\section{RAPD у представителей рода Sorex, включая хромосомные расы Sorex araneus}

\author{
Н.А. Илларионова, С.Г. Потапов, В.Н. Орлов
}

РЕЗЮМЕ. Нами проведен анализ степени генетической близости представителей разных видов рода Sorex (S. araneus, $S$. caecutiens, $S$. minutus, $S$. minutissimus) по данным RAPD-полиморфизма. Кроме того, впервые проанализирован RAPD-полиморфизм 26 представителей 6 хромосомных рас обыкновенной бурозубки (S. araneus) (расы Москва, Иломантси, Санкт-Петербург, Нерусса, Пенза и Сок) на территории Европейской части России. Для проведения RAPD-анализа было отобрано 9 случайных праймеров, дающих наиболее полиморфные и информативные спектры амплифицированных фрагментов ДНК. Число амплифицированных фрагментов ДНК, выявляемых с помощью данных праймеров, колеблется от 24 до 79. Число ясно идентифицированных фрагментов ДНК для полного спектра праймеров было 539. Выявлены локусы, специфичные для представителей различных хромосомных рас Sorex araneus. На основании суммарных матриц RAPD-спектров по 9 праймерам были построены дендрограммы генетического сходства. Это исследование продемонстрировало эффективность метода RAPD для изучения генетической структуры рода Sorex и хромосомных pac $S$. araneus.

КЛЮЧЕВЫЕ СЛОВА: обыкновенная бурозубка, Sorex araneus, хромосомные расы, RAPDs, RAPDPCR.

\section{Introduction}

The genus Sorex is widespread in different biotopes and comprises about 70 species. Because species of Sorex have rather uniform phenotypes, phylogenies based on morphological characters are problematic and species level relationships are still uncertain. Classifications have been based primarily on morphology, karyology and biochemical analyses, each of which has its own limitations. Results of phylogenetic analyses of mitochondrial DNA sequence data (Taberlet et al., 1994; Fumagalli et al., 1996, 1999) contradict interpretations based on karyotype (Zima et al., 1998) and

* Corresponding author biochemical characteristics (George, 1988; George \& Sarich, 1994; Ruedi, 1998).

One species within this genus, the common shrew Sorex araneus Linnaeus, 1758 demonstrates substantial chromosome variation, largely attributable to Robertsonian rearrangements (Searle, 1984). Populations with identical or similar karyotypes are defined as chromosome races, which are, in turn, grouped into larger evolutionary units, karyotypic groups. About 68 chromosome races and 8 karyotypic group of Sorex araneus are currently known (Wójcik et al., 2003; Orlov et al., 2004). Molecular studies of the chromosomal variation in Sorex araneus have included cytochrome $b$ gene sequencing and microsatellite typing (Taberlet et al., 1991, 1994; Lugon-Moulin et al., 1996, 1999a, b; Wyt- 
Table 1. Details of the samples used for RAPD comparison of chromosome races of Sorex araneus.

\begin{tabular}{|c|c|c|c|c|c|}
\hline $\begin{array}{l}\text { Locality } \\
\text { number }\end{array}$ & Sample names & Locality, chromosome race & Coordinates & Karyotype & Source \\
\hline 1 & $\begin{array}{l}4,5,10,20,31 \\
35,48,49\end{array}$ & $\begin{array}{l}\text { Tver Province, Kruticy Village, Russia, } \\
\text { "Moscow" (Mo) }\end{array}$ & $\begin{array}{l}\text { N } 56^{\circ} 10^{\prime} \\
\text { E } 35^{\circ} 00^{\prime}\end{array}$ & $\begin{array}{l}g m, h i, j l \\
k r, n o, p q\end{array}$ & Orlov et al., 1996 \\
\hline 2 & 62 & $\begin{array}{l}\text { Moscow Province, Chernogolovka, } \\
\text { Russia, "Moscow" (Mo) }\end{array}$ & $\begin{array}{l}\text { N } 55^{\circ} 55^{\prime} \\
\text { E } 38^{\circ} 30^{\prime}\end{array}$ & $\begin{array}{l}g m, h i, j l \\
k r, n o, p q\end{array}$ & \begin{tabular}{|l} 
Aniskin \& \\
Lukianova, 1989
\end{tabular} \\
\hline 3 & $\begin{array}{l}233,234,235 \\
240\end{array}$ & $\begin{array}{l}\text { Rostov Province, Cymlyansk District, } \\
\text { Russia, "Neroosa" (Ne) }\end{array}$ & $\begin{array}{l}\text { N } 46^{\circ} 55^{\prime} \\
\text { E } 42^{\circ} 28^{\prime}\end{array}$ & $\begin{array}{l}g / o, h i, j l \\
k / r, m n, p / q\end{array}$ & $\begin{array}{l}\text { Bystrakova et al., } \\
2007\end{array}$ \\
\hline 4 & 353,354 & $\begin{array}{l}\text { Novgorod Province, Russia, "St- } \\
\text { Petersburg" (SPb) }\end{array}$ & $\begin{array}{l}\text { N } 58^{\circ} 00^{\prime} \\
\text { E } 33^{\circ} 40^{\prime}\end{array}$ & $\begin{array}{l}h k, i p, n r \\
m q, g, o\end{array}$ & Orlov et al., 2007 \\
\hline 5 & $383,385,386$ & $\begin{array}{l}\text { Karelia Republic, Ladoga Lake, eastern } \\
\text { bank, Russia, "Ilomantsi" (Il) }\end{array}$ & $\begin{array}{l}\text { N } 60^{\circ} 40^{\prime} \\
\text { E } 33^{\circ} 20^{\prime}\end{array}$ & $\begin{array}{l}g / o, h n, i / p \\
j / l, k / r, m / q\end{array}$ & Orlov et al., 2007 \\
\hline 6 & 69,70 & Tambov Province, Russia, "Penza" (Pe) & $\begin{array}{l}\text { N } 52^{\circ} 40^{\prime} \\
\text { E } 41^{\circ} 50^{\prime}\end{array}$ & $\begin{array}{l}g / m, h n, i / o \\
j l, k r, p / q\end{array}$ & $\begin{array}{l}\text { Bystrakova et al., } \\
2003\end{array}$ \\
\hline 7 & $\begin{array}{l}85,86,87,89 \\
90,101\end{array}$ & $\begin{array}{l}\text { Saratov Province, Rovensky District, } \\
\text { Russia, "Sok" (So) }\end{array}$ & $\begin{array}{l}\text { N } 50^{\circ} 40^{\prime} \\
\text { E } 46^{\circ} 00^{\prime}\end{array}$ & $\begin{array}{l}g o, h n, i p \\
j l, k q, m r\end{array}$ & $\begin{array}{l}\text { Bystrakova et al., } \\
2003\end{array}$ \\
\hline
\end{tabular}

tenbach \& Hausser, 1996; Wyttenbach et al., 1999), fingerprints generated by amplified DNA regions flanked by short interspersed elements (Bannikova et al., 2003) and allozymes (Wójcik, 1993; Brünner \& Hausser, 1996; Wójcik et al., 2002; Ratkiewicz et al., 2003). In the present work, several species of the genus Sorex and chromosome races in Sorex araneus were studied using the RAPD (randomly amplified polymorphic DNA) method.

\section{Material and methods}

Sampling localities. For the interspecific comparisons, shrews were collected in the Komi Republic, Russia (Pechora-Ilych Nature Reserve): three individuals of Sorex araneus (Serov chromosome race), one individual of $S$. caecutiens, two individuals of $S$. minutus and one individual of $S$. minutissimus. A specimen of Crocidura suaveolens was collected in the Voronezh Nature Reserve, Russia to provide an outgroup.

Details of the specimens used for comparisons of chromosome races of Sorex araneus are given in Tab. 1 and Fig. 1. Racial affiliation of specimens was deduced from the literature. Races are listed under their usual names (Wójcik et al., 2003) except Penza which is treated separately from the Mologa chromosome race (see Orlov et al., 2007).

DNA isolation and amplification. DNA was extracted from samples in $96 \%$ ethanol by a standard phenol-chloroform technique (Mathew, 1984). PCR was performed in a $50 \mu \mathrm{L}$ volume containing $10 \mathrm{mM}$ Tris- $\mathrm{HCl}$ (pH 8.0), $50 \mathrm{mM} \mathrm{KCl,} 2 \mathrm{mM} \mathrm{MgCl}, 10 \mathrm{mg}$ BSA, $0.2 \mathrm{mM}$ each deoxynucleoside triphosphate (dATP, dCTP, dGTP and dTTP), $1 \mathrm{mM}$ primer, $50 \mathrm{ng}$ template DNA and $1 \mathrm{U}$ Taq polymerase. Mineral oil $(50 \mu \mathrm{L})$ was layered on top of the reaction mixture, to prevent evaporation (Welsh \& McClelland, 1990). During preliminary experiments more than 60 primers dif- fering in size, GC content and sequence were tested. Only nine of these that yielded reproducible speciesspecific patterns were chosen for the main analysis. These 10-mer oligonucleotide primers provided by

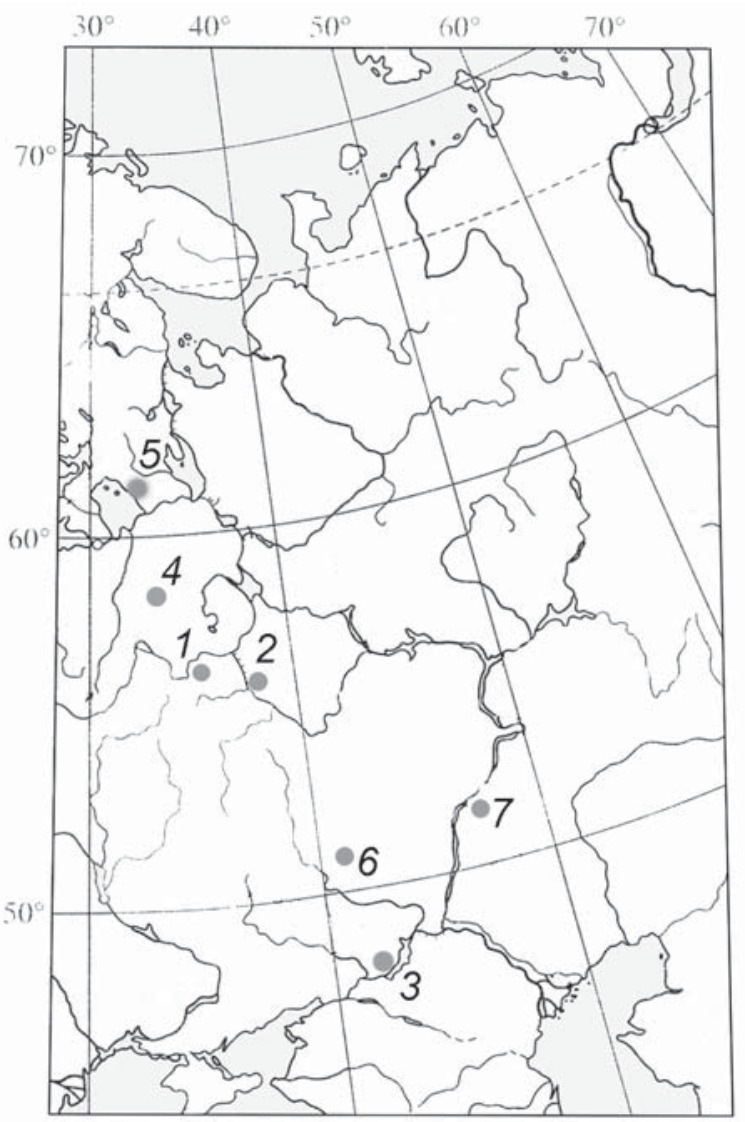

Figure 1. Map of collection localities for representatives of the following Sorex araneus chromosome races: Moscow (1, 2), Neroosa (3), St. Petersburg (4), Ilomantsi (5), Penza (6), Sok (7). 


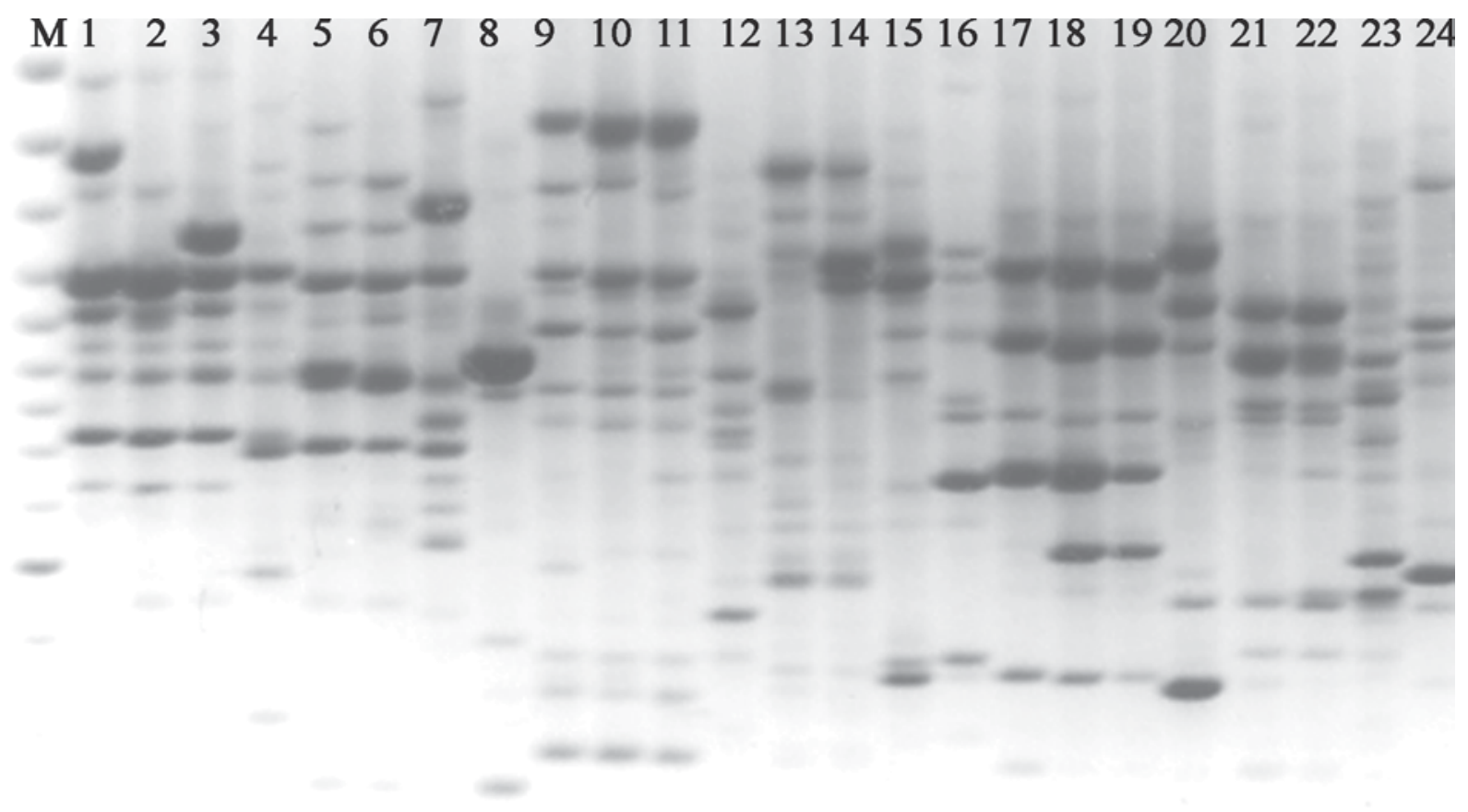

Figure 2. RAPDs using primers OPA-11 (1-8), OPA-12 (9-16) and OPA-19 (17-24) of representatives of the genus Sorex: $1,2,3,9,10,11,17,18,19-S$. araneus; 4, 12, $20-S$. caecutiens; 5, 6, 13, 14, 21, $22-$ S. minutus; 7, 15, $23-S$. minutissimus; 8, 16, 24 - Crocidura suaveolens. M - 100 bp Ladder.

Operon Technologies (Operon Technologies Inc., Alameda, CA, USA) were (5'-3'): OPA-11 (CAATCG CCGT), OPA-12 (TCGGCGATAG), OPA-19 (CAAA CGTCGG), OPE-06 (ACGCATCGCA), OPE-13 (CCA CACTACC), OPW-05 (GGCGGATAAG), OPW-15 (ACACCGGAAC), OPAB-01 (CCGTCGGTAG) and OPAB-04 (GGCACGCGTT).

PCR was conducted in a Tercik thermocycler (DNKTehnologia) as follows: elongation, $1 \mathrm{~min}$ at $72^{\circ} \mathrm{C}$; denaturation, $30 \mathrm{~s}$ at $94^{\circ} \mathrm{C}$; annealing, $30 \mathrm{~s}$ at $37^{\circ} \mathrm{C}$. After 45 cycles, the amplification products were subjected to electrophoresis ( $2 \%$ agarose gels, TAE buffer).

Descriptive statistics and tree reconstruction. The RAPD data were tabulated in the form of a binary data matrix of the "object-sign" type. Nei \& Li's (1979) standard coefficients were calculated to estimate the dissimilarity among individual patterns. This measure was chosen due to its biological meaning and favourable statistical properties (Lamboy, 1994). UPGMA and neighbour-joining (NJ) dendrograms were constructed using the TREECONW software package (Van de Peer \& DeWachter, 1994). For each analysis the values of bootstrap support based on 1000 replicates were obtained.

\section{Results}

The nine primers selected for RAPD analysis generated from 22 to 43 fragments for the individual species studied (Fig. 2) and from 24 to 79 fragments for specimens of the chromosome races of Sorex araneus (Fig. 3 ). The total number of clearly identified DNA frag- ments by all nine primers was 308 (representatives of the genus Sorex) and 539 (representatives of $S$. araneus chromosome races).

Phenetic analysis of Nei-Li distances (UPGMA clustering) of representatives of the genus Sorex demonstrated the presence of three well-differentiated clusters with high bootstrap support, two of which correspond to the separation of the subgenus Sorex Linnaeus, 1758 ( $S$. araneus and $S$. caecutiens) and the subgenus Eurosorex Stroganov, 1952 (S. minutus and S. minutissimus) (Fig. 4). The topologies of the neighbour-joining (Fig. 5) and UPGMA (Fig. 4) trees are very similar.

The neighbour-joining tree of $S$. araneus chromosome races based on Nei-Li distances calculated from RAPD data revealed three well-differentiated clusters with high bootstrap support (Fig. 6). Representatives of the Moscow chromosome races are found in one cluster, with individuals from the Tver Province and Chernogolovka in subclusters. Another cluster is formed by separate groupings of representatives of the Neroosa and Sok chromosome races. The third cluster includes three separate subclusters of representatives of the Ilomantsi, St. Petersburg and Penza chromosome races of $S$. araneus. The topology of the UPGMA dendrogram is very similar to the neighbour-joining tree for these chromosome races.

\section{Discussion}

The UPGMA dendrogram of representatives of the genus Sorex (Fig. 4) demonstrated a division of the 


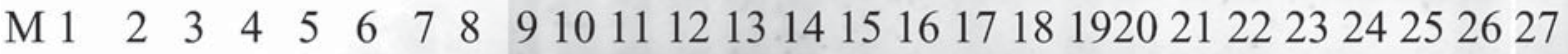

Figure 3. RAPDs using primer OPA-11 for 26 representatives of six chromosome races of the common shrew (Sorex araneus): 1-9 - Moscow, 10-11 - Neroosa, 12-17 - Sok, 18-21 - Penza, 22-23 - St. Petersburg, 24-26 - Ilomantsi, 27 - Sorex caecutiens. M - 100 bp Ladder.

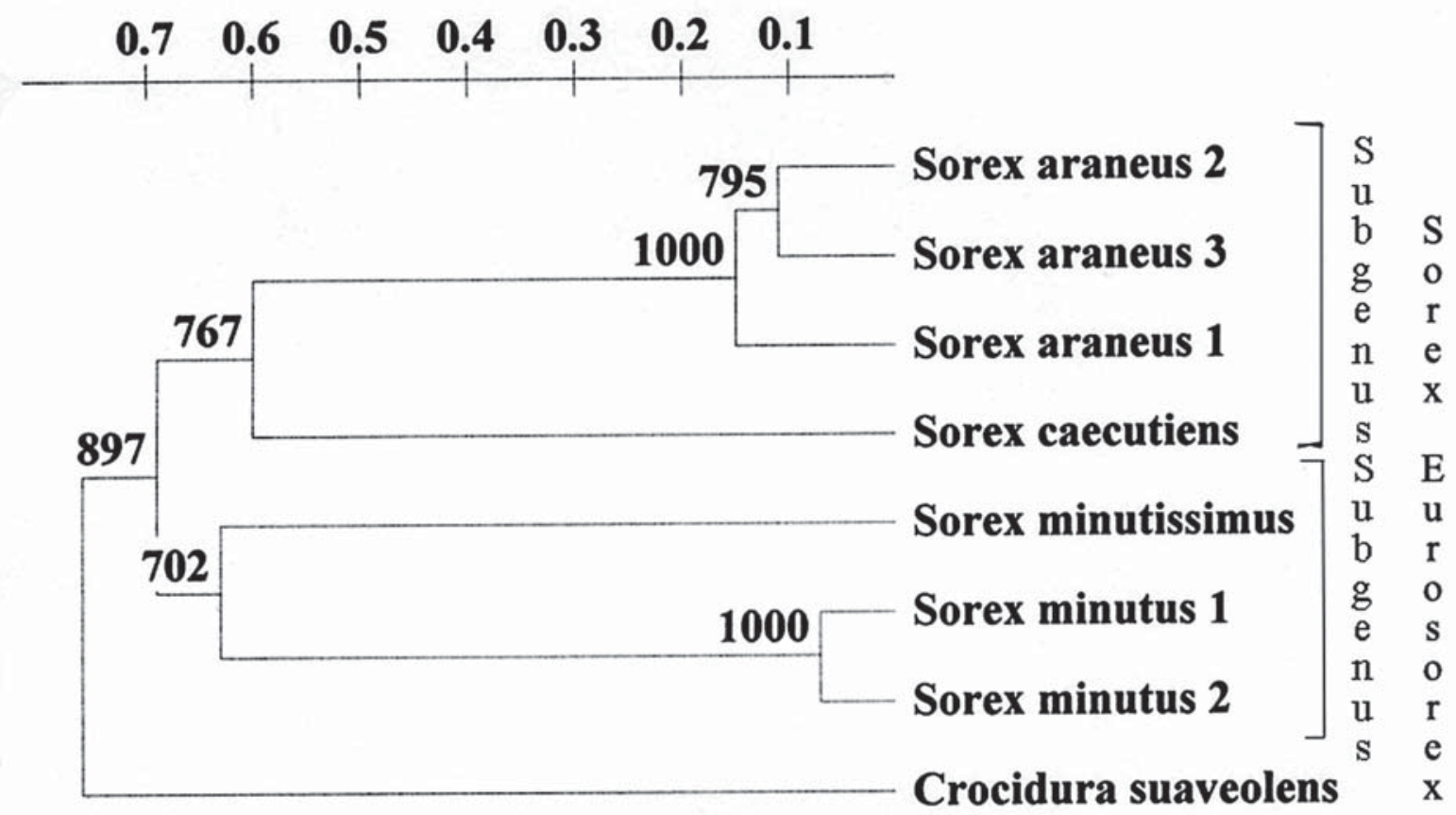

Figure 4. UPGMA dendrogram of representatives of the genus Sorex based on Nei-Li distances calculated from RAPD data. Bootstrap support values are based on 1000 replications. 


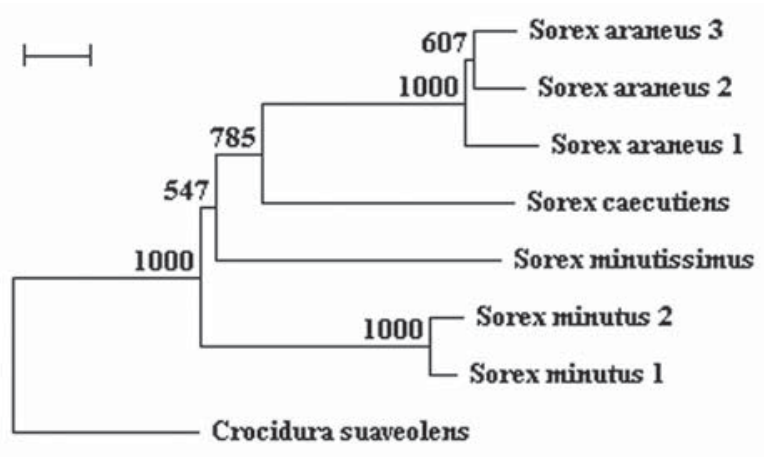

Figure 5. Neighbour-joining tree of representatives of the genus Sorex based on Nei-Li distances calculated from RAPD data. Crocidura suaveolens was used as the outgroup. Bootstrap support values are based on 1000 replications.

genus Sorex into two subgenera: Sorex $(S$. araneus and $S$. caecutiens) and Eurosorex (S. minutus and $S$. minutissimus) (Yudin, 1989). The interspecific genetic distances of representatives of the genus Sorex were approximately twice as high as the inter-racial distances of Sorex araneus. This supports the use of the RAPD method in the resolution of genetic structure in the genus Sorex following previous successes in the genera Microtus (Potapov et al., 1999) and Sicista (Baskevich et al., 2004) and in the Lophuromys flavopunctatus species complex (Lavrenchenko et al., 2001, 2004).
The phylogenetic affinities of the chromosome races of the common shrew in European Russia are rather confusing on the basis of our RAPD results. Among the races examined in the present study, the Moscow race obviously belongs to the West European karyotypic group, WEKG (Orlov et al., 1996). The representatives of the Moscow chromosome race form a separate group on the trees. The karyotypes of the Neroosa and Penza chromosome races may be defined as derivatives of the WEKG that evolved during its eastward postglacial expansion (Bulatova et al., 2000). These races form different clusters on the molecular trees. On the contrary, the Ilomantsi race (Finnish family of races) and St. Petersburg race (East-Baltic family) - differ slightly with respect to RAPD patterns, suggesting low genetic differentiation between them. The association of these races in one cluster with the Neroosa chromosome race suggests their ancient contact. The Sok chromosome race belongs to the widely distributed Ural family of races and forms a separate group on the trees together with the unrelated Penza chromosome race. Overall, the composition and cluster structure of the dendrogram obtained relate to the scheme for evolution of common shrew chromosome races developed by Orlov et al. $(2004,2006)$.

The topology of the trees based on RAPDs show differences from those generated by analysis of amplified DNA regions flanked by short interspersed elements (Bannikova et al., 2003), suggesting markerspecific patterns. However, there is a notable concor-

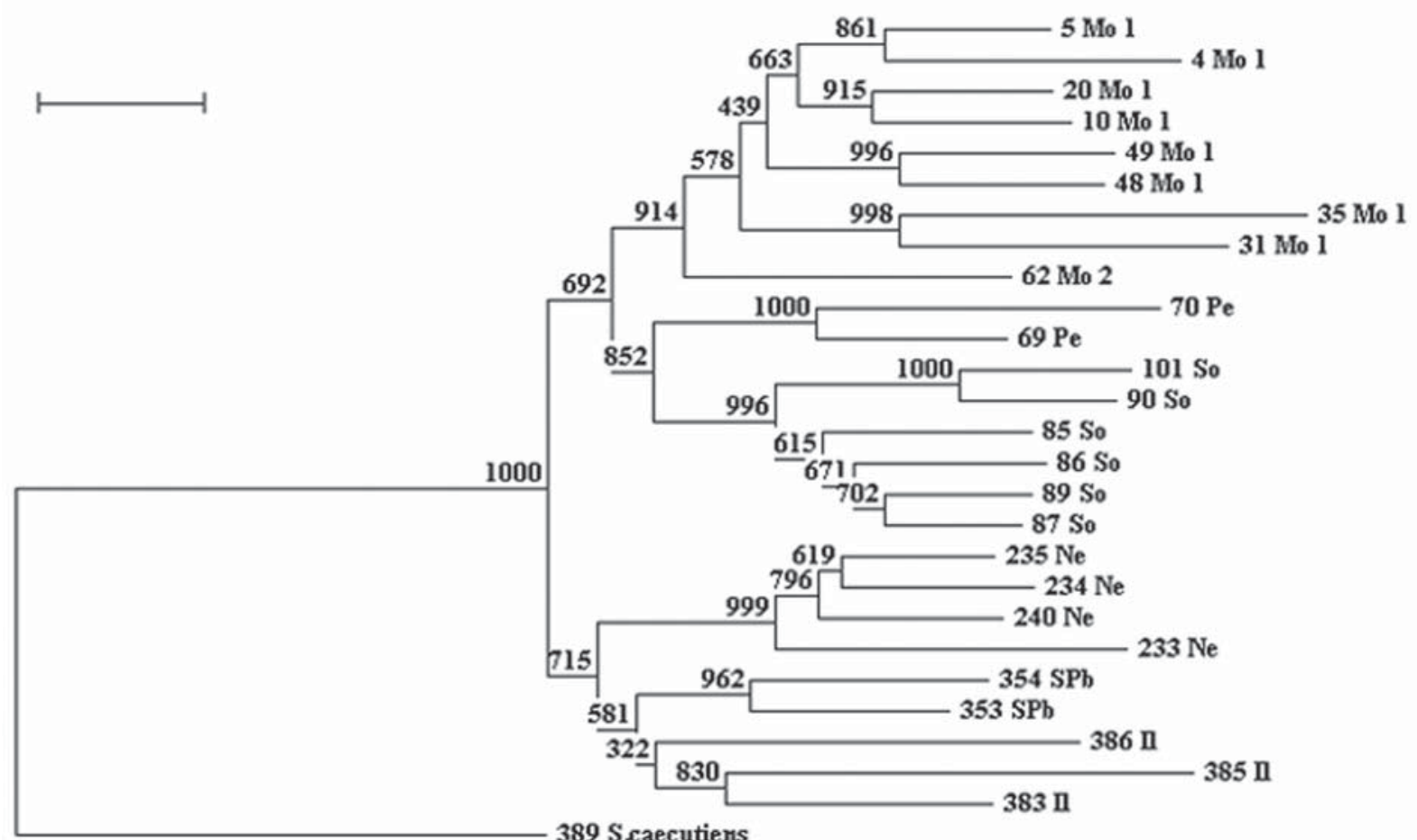

Figure 6. Neighbour-joining tree of representatives of chromosome races of Sorex araneus based on Nei-Li distances calculated from RAPD data. Sorex caecutiens was used as the outgroup. Bootstrap support values are based on 1000 replications. 
dance between the RAPD data and results from the analysis from mtDNA cytochrome $b$ nucleotide sequence (Balakirev et al., 2007).

ACKNOWLEDGMENTS. The authors are deeply indebted to the reviewers for valuable comments and to the editors for linguistic corrections. This study was supported by the Russian Foundation for Basic Research (grant No. 03-0448908) and the Research Program of the Russian Academy of Science "Dynamics of Genomes of Plant and Animals".

\section{References}

Aniskin V.M. \& Lukianova I.V. 1989. [A new chromosome race and the analysis of hybridization zone of two karyoforms of Sorex araneus (Insectivora, Soricidae)] // Doklady Akademii Nauk SSSR. Vol.309. P.1260-1262 [in Russian].

Balakirev A.E, Illarionova N.A., Potapov S.G. \& Orlov V.N. 2007. DNA polymorphism within Sorex araneus from European Russia as inferred from mtDNA cytochrome $b$ sequences // Russian Journal of Theriology. Vol.6. No.1. P.35-42.

Bannikova A.A., Bulatova N.S., Krysanov E.Y. \& Kramerov D.A. 2003. DNA polymorphism within Sorex araneus and two congeneric species as inferred from inter-SINEPCR // Mammalia. Vol.67. P.263-274.

Baskevich M.I., Okulova N.M., Potapov S.G. \& Warshawskii A.A. 2004. [Diagnostics, distribution and evolution of the unstriped birch miceSicista (Rodentia, Dipodoidea) in the Caucasus] // Zoologicheskii Zhurnal. Vol.83. P.220-233 [in Russian, with English summary].

Brünner H. \& Hausser J. 1996. Genetic and karyotypic structure of a hybrid zone between the chromosome races Cordon and Valais in the common shrew, Sorex araneus // Hereditas. Vol.125. P.147-158.

Bulatova N., Searle J.B., Bystrakova N., Nadjafova R., Shchipanov N. \& Orlov V. 2000. The diversity of chromosome races in Sorex araneus from European Russia // Acta Theriologica. Vol.45. Suppl.1. P.33-46.

Bystrakova N., Bulatova N., Kovalskaya Y., Shchipanov N., Kalinin A., Nadjafova R. \& Searle J.B. 2003. Geographical limits of chromosome races of the common shrew Sorex araneus L. in the Middle Volga (East European Russia) // Mammalia. Vol.67. P.187-191.

Bystrakova N.V., Shchipanov N.A., Bulatova N.S., Sheftel B.I., Nadjafova R.S., Pavlova S.V., Demidova T.B., Bobretsov A.V, Aleksandrov D.Yu., Kalinin A.A., Kouptsov A.V., Volkova A.T., Oleinichenko V.Yu. \& Searle J.B. 2007. New data on the geographic distribution of chromosome races of Sorex araneus (Soricidae, Eulipotyphla) in European Russia // Russian Journal of Theriology. Vol.6. No.1. P.105-109.

Fumagalli L., Hausser J., Taberlet P., Gielly L. \& Stewart D.T. 1996. Phylogenetic structure of the Holarctic Sorex araneus group and its relationships with S. samniticus, as inferred from mtDNA sequences // Hereditas. Vol.125. P.191-199.

Fumagalli L., Taberlet P., Stewart D.T., Gielly L., Hausser J. \& Vogel P. 1999. Molecular phylogeny and evolution of Sorex shrews (Soricidae: Insectivora) inferred from mi- tochondrial DNA sequence data // Molecular Phylogenetics and Evolution. Vol.11. P.222-235.

George S.B. 1988. Systematics, historical biogeography, and evolution of the genus Sorex // Journal of Mammalogy. Vol.69. P.443-461.

George S.B. \& Sarich V.M. 1994. Albumin evolution in the Soricinae and its implications for the phylogenetic history of the Soricidae // Merritt J.F., Kirkland G.L., Jr. \& Rose R.K. (eds.). Advances in the Biology of Shrews. Carnegie Museum Natural History Special Publication, Pittsburgh. P.289-293.

Halkka L., Söderlund V., Skarén U. \& Heikkilä J. 1987. Chromosome polymorphism and racial evolution of Sorex araneus L. in Finland // Hereditas. Vol.106. P.257275.

Lamboy W.F. 1994. Computing genetic similarity coefficients from RAPD data: the effects of PCR artifacts // Genome Research. Vol.4. P.31-37.

Lavrenchenko L.A., Potapov S.G., Lebedev V.S. \& Ryskov A.P. 2001. The phylogeny and systematics of the endemic Ethiopian Lophuromys flavopunctatus species complex based upon random amplified polymorphic DNA (RAPD) analysis // Biochemical Systematics and Ecology. Vol.29. P.1139-1151.

Lavrenchenko L.A., Verheyen E., Potapov S.G., Lebedev V.S., Bulatova N.Sh., Aniskin V.M., Verheyen W.N. \& Ryskov A.P. 2004. Divergent and reticulate processes in evolution of Ethiopian Lophuromys flavopunctatus species complex: evidence from mitochondrial and nuclear DNA differentiation patterns // Biological Journal of the Linnean Society. Vol.83. P.301-316.

Lugon-Moulin N., Wyttenbach A., Brünner H., Goudet G. \& Hausser J. 1996. Study of gene flow through a hybrid zone in the common shrew (Sorex araneus) using microsatellites // Hereditas. Vol.125. P.159-168.

Lugon-Moulin N., Brünner H., Balloux F., Hausser J. \& Goudet G. 1999a. Do riverine barriers, history or introgression shape the genetic structuring of the common shrew (Sorex araneus) population? // Heredity. Vol.83. P.155-161.

Lugon-Moulin N., Brünner H., Wyttenbach A., Hausser J. \& Goudet G. 1999b. Hierarchical analysis of genetic differentiation in a hybrid zone of Sorex araneus (Insectivora, Soricidae) // Molecular Ecology. Vol.8. P.419-432.

Orlov V., Bulatova N., Kozlovsky A., Nadjafova R. \& Searle J.B. 1996. Karyotypic variation of the common shrew (Sorex araneus) in European Russia: preliminary results // Hereditas. Vol.125. P.117-121.

Orlov V.N., Bulatova N.Sh., Kozlovsky A.I. \& Balakirev A.E. 2004. [Hierarchy of intraspecific taxa of the common shrew Sorex araneus L. (Insectivora), and taxonomic structure of species in mammals] // Zoologicheskii Zhurnal. Vol. 83. P.199-212 [in Russian, with English summary].

Orlov V.N., Kozlovsky A.I., Okulova N.M. \& Balakirev A.E. 2007. Postglacial recolonisation of European Russia by the common shrew Sorex araneus // Russian Journal of Theriology. Vol.6. P.97-104.

Orlov V.N., Kozlovsky A.I., Potapov S.G., Illarionova N.A., Irchin S.Yu. \& Balakirev A.E. 2006. [Refugial structure of species areas during the late Pleistocene-Holocene as 
inferred from molecular-genetic methods] // Savinetsky A.B. (ed.). Dynamics of the Recent Ecosystems over the Holocene. Moskva: KMK Scientific Press Ltd. P.174 179 [in Russian].

Polyakov A.V., Zima J., Searle J.B., Borodin P.M. \& Ladygina T. 2000. Chromosome races of the common shrew Sorex araneus in the Ural Mts: a link between Siberia and Scandinavia? //Acta Theriologica. Vol.45. Suppl.1. P.19-26.

Potapov S.G., Orlov V.N., Kovalskaja J.M., Malygin V.M. \& Ryskov A.P. 1999. [Genetic differentiation in the voles of the tribe Arvicolini (Cricetidae, Rodentia) using DNA taxonprint and analysis RAPD-PCR] // Genetika. Vol.35. P.484-492 [in Russian].

Ratkiewicz M., Fedyk S., Banaszek A., Chętnicki W., Szałaj K., Gielly L. \& Taberlet P. 2002. The evolutionary history of the two karyotypic groups of the common shrew, Sorex araneus, in Poland// Heredity. Vol.88. P.235-242

Ratkiewicz M., Banaszek A., Jadwiszczak K., Chętnicki W. \& Fedyk S. 2003. Genetic diversity, stability of population structure and barriers to gene flow in a hybrid zone between two Sorex araneus chromosome races // Mammalia. Vol.67. P.275-283.

Ruedi M. 1998. Protein evolution in shrews // Wójcik J.M. \& Wolsan M. (eds.). Evolution of Shrews. Białowieża: Mammal Research Institute, Polish Academy of Sciences. P.269-294.

Searle J.B. 1984. Three new karyotypic races of the common shrew Sorex araneus (Mammalia: Insectivora) and a phylogeny // Systematic Zoology. Vol.33. P.184-194.

Searle J. B. \& Wójcik J.M. Chromosomal evolution: the case of Sorex araneus // Wójcik J.M. \& Wolsan M. (eds.). Evolution of Shrews. Białowieża: Mammal Research Institute, Polish Academy of Sciences. P.219-268.
Taberlet P., Fumagalli L. \& Hausser J. 1994. Chromosome versus mitochondrial DNA evolution: tracking the evolutionary history of the southwestern European populations of the Sorex araneus group (Mammalia, Insectivora) // Evolution. Vol.43. P.623-636.

Welsh J. \& McClelland M. 1990. Fingerprinting genomes using PCR with arbitrary primers // Nucleic Acids Research. Vol.18. P.7213-7218.

Wójcik J.M. 1993. Chromosome races of the common shrew Sorex araneus in Poland: a model of karyotype evolution // Acta Theriologica. Vol.38. P.315-338.

Wójcik J.M., Ratkiewicz M. \& Searle J.B. 2002. Evolution of the common shrew Sorex araneus: chromosome and molecular aspects // Acta Theriologica. Vol.47. Suppl.1. P.139-167.

Wyttenbach A. \& Hausser J. 1996. The fixation of metacentric chromosomes during the chromosome evolution in the common shrew (Sorex araneus, Insectivora) // Hereditas. 1996. Vol.125. P.209-217.

Wyttenbach A., Narain Y. \& Fredga K. 1999. Genetic structuring and gene flow in a hybrid zone between two chromosome races of the common shrew (Sorex araneus, Insectivora) revealed by microsatellites // Heredity. Vol.82. P.79-88.

Yudin B.S. 1989. [Insectivorous Mammals of Siberia]. Novosibirsk: Nauka. [In Russian].

Zima J., Fedyk S., Fredga K., Hausser J., Mishta A., Searle J.B., Volobouev V.T. \& Wójcik J.M. 1996. The list of the chromosome races of the common shrew (Sorex araneus) // Hereditas. Vol.125. P.97-107.

Zima J., Lukáčová L. \& Macholán M. 1998. Chromosomal evolution in shrews // Wójcik J.M. \& Wolsan M. (eds.). Evolution of Shrews. Białowieża: Mammal Research Institute, Polish Academy of Sciences. P.175-218. 